\title{
AÇÕES COLETIVAS E CONTROLE DIFUSO DE CONSTITUCIONALIDADE: PONDERAÇÕES À LUZ DA NOVA SISTEMÁTICA DE COISA JULGADA INTRODUZIDA PELO CÓDIGO DE PROCESSO CIVIL DE 2015
}

\author{
Tereza Cristina Sorice Baracho Thibau* \\ Thaís Costa Teixeira Viana**
}

\begin{abstract}
Resumo: Essencialmente, o controle difuso de constitucionalidade, incidental às lides intersubjetivas, não tem o condão de retirar normas do ordenamento jurídico ou modificar definitivamente sua interpretação, restringindo-se às partes processuais. É controvertido, contudo, seu cabimento em ações coletivas, cuja coisa julgada produz efeitos erga omnes ou ultra partes, sobretudo diante da nova regulamentação da coisa julgada, no Código de Processo Civil de 2015 (CPC/15), quanto a questões decididas incidentalmente. Mediante pesquisa jurídico-dogmática e doutrinária, à luz do direito processual civil e constitucional, objetiva-se analisar a aplicabilidade do controle difuso de constitucionalidade em ações coletivas, sob a sistemática do $\mathrm{CPC} / 15$.
\end{abstract}

Palavras-Chave: Controle de Constitucionalidade. Controle Difuso. Ações Coletivas. Coisa Julgada Erga Omnes. Questão Incidental.

\section{CLASS ACTIONS AND DIFFUSE CONTROL OF CONSTITUTIONALITY: PONDERATIONS IN THE LIGHT OF THE NEW RES JUDICATA SYSTEM INTRODUCED BY THE CODE OF CIVIL PROCEDURE OF 2015}

\begin{abstract}
Essentially, the diffuse control of constitutionality, incidental to intersubjective lawsuits, may not remove norms from the legal system or permanently modify its interpretation, restricting itself to the parties of the lawsuit. It is controversial, however, its applicability to class actions, which produce erga omnes and ultra partes res judicatas, especially regarding the new res judicata regulation in the Code of Civil Procedure of 2015 (CPC/15), concerning issues decided incidentally. Throughout legal-dogmatic and doctrinal research, based on civil procedure and constitutional law, it is aimed to analyze the applicability of diffuse control of constitutionality in class actions, under the $\mathrm{CPC} / 15$.
\end{abstract}

Key-Words: Constitutionality Control. Diffuse Control. Class Actions. Erga Omnes Res Judicata. Incidental Issue.

\footnotetext{
* Doutora e Mestre em Direito pela UFMG. Professora Associada de Direito e Processo Civil e Coletivo na FDUFMG. Membro do IDPro (Instituto de Direito Processual). Bacharela em Pedagogia pela PUC-Minas. Endereço eletrônico: thibau@ gmail.com.

** Mestranda e Bacharela em Direito pela Universidade Federal de Minas Gerais. Pesquisadora do Programa Universitário de Apoio às Relações de Trabalho e à Administração da Justiça (PRUNART/UFMG). Advogada. Endereço eletrônico: thaisctv@ gmail.com.
} 


\section{AÇÕES COLETIVAS E CONTROLE DIFUSO DE CONSTITUCIONALIDADE: PONDERAÇÕES À LUZ DA NOVA SISTEMÁTICA DE COISA JULGADA INTRODUZIDA PELO CÓDIGO DE PROCESSO CIVIL DE 2015}

\section{INTRODUÇÃO}

A posição de supremacia ocupada pela Constituição da República Federativa do Brasil (CR/88) exige que exista, em torno de si, minucioso sistema de controle de constitucionalidade voltado à apuração preventiva ou repressiva da compatibilidade entre o texto constitucional e as leis ou atos normativos, sempre de natureza infraconstitucional. No caso brasileiro, esse controle é exercido mormente no âmbito do Poder Judiciário, pela via do controle concentrado de constitucionalidade (vocacionado à resolução definitiva da questão, com efeitos irradiáveis a toda a coletividade) e do controle difuso de constitucionalidade (realizado à luz de casos concretos e direcionado às partes de determinada lide intersubjetiva).

Ao contrário do que se verifica com o controle concentrado, no que concerne ao controle difuso, não se cogita pretensão de alcance coletivo, mesmo porque é realizado à luz do caso concreto no âmbito dos mais diversos juízos ou Tribunais, e apreciado incidentalmente enquanto questão prejudicial à resolução meritória da lide.

Durante a vigência do Código de Processo Civil de 1973 (CPC/73), esta última modalidade de controle de constitucionalidade era majoritariamente admitida nas diversas espécies de lides intersubjetivas, dentre as quais, inclusive, as ações coletivas, haja vista sua natureza prejudicial incidental. Quanto às ações coletivas, interpretava-se que apesar de produzirem coisa julgada erga omnes ou ultra partes, estes efeitos não seriam aplicáveis à decisão em controle de constitucionalidade, à medida que a norma processual civil comum não estendia a formação de coisa julgada às questões prejudiciais decididas incidentalmente.

Contudo, a promulgação do Código de Processo Civil de 2015 (CPC/15) ampliou o espectro de incidência da coisa julgada, de forma a se alcançarem também as questões prejudiciais, ainda que decididas incidentalmente. Aplicável subsidiariamente ao sistema integrado de tutela processual coletiva, referida norma passou a produzir efeitos no âmbito de ações coletivas, pelo que se tornou imperiosa a revisitação dos debates acerca do cabimento de controle difuso de constitucionalidade no bojo destas ações.

Este estudo volta-se à discussão de tal questão, objetivando verificar a possibilidade de se realizar controle difuso de constitucionalidade em ações coletivas, bem como as nuances da efetivação desse controle, à luz da normatização da coisa julgada introduzida pelo CPC/15. Para tanto, realizou-se pesquisa doutrinária e legislativa, comparando-se as ordens processuais 
civis do CPC/73 e do CPC/15, no que tange ao instituto da coisa julgada, mediante vertente metodológica jurídico-dogmática. A análise se revestiu, ainda, de viés interdisciplinar, combinando noções de direito processual civil e constitucional.

\section{CONTROLE DE CONSTITUCIONALIDADE NO BRASIL: DO PROCESSO COLETIVO ESPECIAL À PRETENSÃO NÃO COLETIVIZANTE DO CONTROLE DIFUSO}

A CR/88 ocupa papel de inquestionável centralidade no ordenamento jurídico pátrio: alicerça-se enquanto norma fundamental à luz da qual deve ser interpretado todo o restante do conjunto normativo que regula os mais variados aspectos da vida em sociedade, das relações entre os indivíduos, ou ainda entre estes e o Estado. Além disso, ao se situar em patamar hierárquico proeminente, em relação às leis e atos normativos, estabelece a CR/88, inclusive, procedimentos diferenciados à sua alteração e rol de cláusulas consideradas pétreas (que não poderiam ser abolidas), de forma a tornar evidente sua rigidez ${ }^{1}$.

Leis e atos normativos pretéritos à promulgação da $\mathrm{CR} / 88$, para que continuassem produzindo seus efeitos regularmente, precisariam ser recepcionados por esta, vale dizer, deveriam revelar-se consentâneos aos princípios e normas regentes do novo Estado Democrático de Direito que foi instituído. Por sua vez, como consequência dessa supremacia e rigidez do texto constitucional, às leis e aos atos normativos editados e promulgados após o início da vigência da CR/88, passou-se a exigir que a observassem, seja no que concerne ao seu processo legislativo, forma ou conteúdo.

Com vistas a se garantir essa observância, regulamentou-se no ordenamento jurídico brasileiro um sistema de controle de constitucionalidade, por intermédio do qual se poderia verificar a "parametricidade entre a Constituição e a Legislação infraconstitucional" (FERNANDES, 2011, p.895) e proceder, em casos de comprovada inconstitucionalidade, à invalidação da referida lei. Trata-se de controle passível de ser exercido tanto ao longo do processo legislativo e, portanto, antes da promulgação da lei ou ato normativo (por exemplo, por intermédio do veto pelo chefe do Poder Executivo, ou da impetração de mandado de

\footnotetext{
${ }^{1}$ Consoante leciona FERNANDES (2011, pp.14-16), tradicionalmente, quanto à sua estabilidade, classificam-se as Constituições como rígidas (que regulam, em seu próprio texto, procedimentos especiais e mais dificultosos à sua modificação), flexíveis (que admitem sua alteração pelos mesmos procedimentos aplicáveis à legislação infraconstitucional), semirrígidas (possuindo porção rígida e porção flexível), fixas (alteráveis apenas pelo Poder Constituinte Originário) ou imutáveis.
} 


\section{AÇÕES COLETIVAS E CONTROLE DIFUSO DE CONSTITUCIONALIDADE: PONDERAÇÕES À LUZ DA NOVA SISTEMÁTICA DE COISA JULGADA INTRODUZIDA PELO CÓDIGO DE PROCESSO CIVIL DE 2015}

segurança por parlamentar), quanto após o início de sua vigência (por exemplo, pela via de ação direta de inconstitucionalidade), apesar de ser esta última hipótese considerada regra no caso brasileiro (FERNANDES, 2011, p.910).

Este controle pode ser ainda exercido por órgãos do Poder Legislativo, Executivo ou Judiciário, sendo apontado como majoritário, no Brasil, aquele pela via judicial:

Em nosso atual ordenamento jurídico-constitucional existe o controle político de constitucionalidade, que é realizado, por exemplo, pelo Poder Legislativo e pelo Poder Executivo, porém, não como regra, mas excepcionalmente (como exceção), não havendo como se afirmar sobre a existência de um sistema ou de uma verdadeira matriz política em terrae brasilis, como a existente na França. [...] O Brasil adota como regra geral o controle de natureza (tradicionalmente) judicial. (FERNANDES, 2011, p.907)

No que tange a esse controle de constitucionalidade pelas vias judiciais, admite o ordenamento jurídico brasileiro que seja exercido de forma concentrada ou de forma difusa, ou seja, por uma única Corte legitimada a avaliar a harmonização entre as leis e o texto constitucional ou por todos os órgãos do Poder Judiciário, respectivamente. Ambas as formas de controle, contudo, apresentam procedimentos e efeitos nitidamente diferentes entre si, haja vista o contraste entre a pretensão coletivizante do controle concentrado e o viés casuístico e individual do controle difuso.

Nas palavras de ALMEIDA (2003, p.157), o controle concentrado de constitucionalidade seria exercido por intermédio do direito processual coletivo especial, enquanto "instrumento fundamental potencializado de proteção do Estado Democrático de Direito contra as investidas normativas autoritárias e incompatíveis com os direitos e garantias constitucionais fundamentais". Integrariam esse direito processual coletivo especial mecanismos como a ação direta de inconstitucionalidade (ADI), a ação declaratória de constitucionalidade (ADC), a ação direta de inconstitucionalidade por omissão (ADO) e a arguição de descumprimento de preceito fundamental (ADPF), voltados à apreciação da constitucionalidade de leis e atos normativos em abstrato, ou seja, de forma desvinculada de um caso concreto.

Por se voltar à avaliação da constitucionalidade de forma abstrata ou em tese, por uma Corte legitimada a fazê-lo (no caso da análise à luz da CR/88, pelo Supremo Tribunal Federal - STF), o controle concentrado de constitucionalidade pode conduzir, naturalmente, à invalidação de determinada lei ou ato normativo, afetando, assim, de forma homogênea e 
indivisível, toda uma coletividade, razão pela qual optou ALMEIDA (2003, p.158) por enquadrar essa modalidade de controle no gênero dos processos coletivos, a partir da subdivisão em "direito processual coletivo comum" e "direito processual coletivo especial".

Trata-se, como ocorre no Brasil, de um processo cujo objeto é o controle em abstrato da constitucionalidade, dos atos normativos federais, estaduais ou municipais em face da Constituição Federal, ou das leis ou atos normativos estaduais ou municipais, em face da Constituição Estadual, nesse caso quando se tratar de controle a ser exercido pelos Tribunais dos Estados. A matéria é, portanto, exclusivamente de direito e a tutela é de direito objetivo e não subjetivo diferentemente do que ocorre no direito processual coletivo comum. Apesar disso, o interesse por um sistema jurídico coeso, coerente $e$ constitucional é de regra difuso, pois pertence a todos aqueles que estão sob a regulamentação desse sistema jurídico.

[...] A decisão a ser proferida no controle em abstrato de constitucionalidade irá atingir, de alguma forma, o interesse de uma comunidade de pessoas, o que também guarda certa semelhança com o direito processual coletivo comum, como é de se extrair dos limites subjetivos da coisa julgada coletiva regulamentados pelo art.103 do Código de Defesa do Consumidor. (ALMEIDA, 2003, p.158)

Não restam dúvidas, portanto, de que permeia o controle concentrado de constitucionalidade, um propósito de coletivização, vale dizer, de se irradiar de forma erga omnes os efeitos da coisa julgada no seu âmbito produzida, consoante leciona o parágrafo único do art.28, da Lei n. ${ }^{\circ}$ 9.868/1999. Tem-se, portanto, que tanto a declaração de constitucionalidade, quanto a de inconstitucionalidade, de uma lei ou ato normativo, quando realizadas em sede de controle concentrado, têm "eficácia contra todos", além de vincular o Poder Judiciário e a Administração Pública federal, estadual e municipal.

Diferentemente, entretanto, se opera em relação ao controle difuso de constitucionalidade, na medida em que este apresenta nítido viés casuístico e individual, sem qualquer pretensão de coletivização. Ocorre que o controle difuso de constitucionalidade, por essência, viabiliza a análise da harmonização entre uma lei ou ato normativo e o texto constitucional pelos mais variados órgãos do Poder Judiciário (desde juízes de primeiro grau a Tribunais Superiores), à luz de um caso concreto, pretendendo se tornar vinculativo apenas às partes de tal lide, restringindo-se ainda ao objeto desta.

\subsection{A Natureza Prejudicial Incidental da Decisão em Controle Difuso de Constitucionalidade}

\footnotetext{
${ }^{2}$ Esclarece-se, para fins metodológicos, que, no presente trabalho, a nomenclatura "ação(ões) coletiva(s)" será utilizada exclusivamente em referência ao "direito processual coletivo comum".
} 


\section{AÇÕES COLETIVAS E CONTROLE DIFUSO DE CONSTITUCIONALIDADE: PONDERAÇÕES À LUZ DA NOVA SISTEMÁTICA DE COISA JULGADA INTRODUZIDA PELO CÓDIGO DE PROCESSO CIVIL DE 2015}

O controle difuso de constitucionalidade adotado no Brasil inspira-se no sistema norteamericano, consagrado no caso Marbury vs. Madison e que possui como características:

[...] a) esse controle de atos normativos em relação à Constituição seria feito pelo Poder Judiciário e, no caso norte-americano, por todos os seus membros (todos os Juízes e Tribunais) de forma hodiernamente chamada de difusa; b) também é importante salientar que o mesmo seria afeto sempre a casos concretos a serem solvidos pelo Poder Judiciário no desempenho comum de sua função jurisdicional, controlando-se a constitucionalidade de modo incidental e gerando efeitos tradicionalmente intitulados de interpartes (pelo menos a priori); c) a declaração de inconstitucionalidade, no que tange à perspectiva temporal, geraria efeitos ex tunc (retroativos), sendo o ato normativo considerado inconstitucional desde o dia em que surgiu no ordenamento. Nesse sentido, a decisão é meramente declaratória de uma inconstitucionalidade existente desde a origem da lei ou do ato normativo impugnado. (FERNANDES, 2011, p.904)

Tem-se, portanto, que se trataria de modalidade de controle que poderia ser realizada pelos diversos órgãos do Poder Judiciário, frente a caso concreto, declarando a inconstitucionalidade de lei ou ato normativo, via de regra, desde sua origem, às partes que integram a lide. Cada um desses elementos merece análise mais pormenorizada.

Na medida em que é exercido no bojo de lides intersubjetivas, é da essência do controle difuso de constitucionalidade que sua realização se dê, seja por juízes de primeiro grau, seja no âmbito de Tribunais. No que concerne a este aspecto, contudo, merece destaque o art.97 da $\mathrm{CR} / 88$, que consagra a chamada "cláusula de reserva de Plenário", segundo a qual se torna vedado aos órgãos fracionários de Tribunais a declaração de inconstitucionalidade de lei ou ato normativo, prerrogativa esta que passa a ser restrita ao Pleno ou Órgão Especial do respectivo Tribunal (em maioria absoluta). Não há qualquer proibição, entretanto, para que juízes monocráticos, de primeiro grau, declarem essa inconstitucionalidade em controle difuso. Ressalva-se a Súmula Vinculante n. ${ }^{\circ}$ 10, do STF, segundo a qual "viola a cláusula de reserva de plenário [...] a decisão de órgão fracionário de tribunal que, embora não declare expressamente a inconstitucionalidade de lei ou ato normativo do poder público, afasta sua incidência, no todo ou em parte".

Por se tratar de controle passível de realização por qualquer juízo ou Tribunal, tem-se que a constitucionalidade da lei ou ato normativo não poderia integrar o objeto principal, a questão central, da lide, caso contrário, só possuiriam legitimidade para julgamento o STF, caso o parâmetro de controle fosse a CR/88, ou os Tribunais de Justiça dos Estados, caso esse parâmetro fosse a respectiva Constituição Estadual. Além disso, se porventura a análise da 
constitucionalidade compusesse o objeto principal da lide, estar-se-ia diante de modalidade de controle concentrado e não difuso de constitucionalidade.

O controle difuso tem por característica principal o fato de se dar à luz de um caso concreto submetido ao crivo do Poder Judiciário, e, como regra, sem pretensões coletivizantes. A análise da constitucionalidade, logo, figura tão somente como "questão de fundo"3, pressuposto ao julgamento meritório da questão principal sobre a qual versar a lide, tratandose, assim, de "questão prejudicial". Por não integrar o objeto principal da ação, é consequentemente decidida de forma incidental e, como leciona FERNANDES (2011, pp.909 e 919), pela via de exceção, situando-se suas discussões na seara da causa de pedir e não do pedido.

Dessa forma, por se tratar de questão prejudicial, decidida incidentalmente, apenas enquanto pressuposto ao julgamento de mérito de determinada lide intersubjetiva, tem-se que a declaração de (in)constitucionalidade em controle difuso produz seus efeitos tão somente no âmbito do caso concreto ao qual foi apreciada, restringindo-se às partes que integraram a lide processual (efeitos inter partes). Outrossim, a fim de oferecer substrato apto a solucionar referida lide intersubjetiva, tal declaração de (in)constitucionalidade apresenta, como regra, efeitos ex tunc, ou seja, retroativos à origem da lei ou ato normativo.

\section{A FORMAÇÃO DE COISA JULGADA SOBRE QUESTÕES PREJUDICIAIS DECIDIDAS INCIDENTALMENTE NO CÓDIGO DE PROCESSO CIVIL DE 2015}

Traz a lição de DIDIER JR. et al (2016a, pp.546-547) que os conceitos de prejudicialidade e incidentalidade não se confundiriam, nem poderiam ser considerados sinônimos, no direito processual civil brasileiro. Pelo contrário, a questão prejudicial, vale dizer, aquela cuja decisão consistiria em antecedente necessário e determinante ao conteúdo do julgamento de outra questão, poderia ser principal ou incidental, conforme integrasse o objeto da lide ou a fundamentação da decisão, respectivamente. A título de exemplificação, os mesmos autores expõem que, em uma ação de alimentos, a decisão acerca da filiação seria prejudicial incidental à decisão da questão principal (2016a, p.549), ao passo que, em uma ação de investigação de paternidade cumulada com alimentos, a decisão acerca da filiação continuaria a ser prejudicial, porém principal, por integrar o objeto da lide (2016a, p.554).

\footnotetext{
${ }^{3}$ A expressão é utilizada por FERNANDES, 2011, p.909.
} 


\section{AÇÕES COLETIVAS E CONTROLE DIFUSO DE CONSTITUCIONALIDADE: PONDERAÇÕES À LUZ DA NOVA SISTEMÁTICA DE COISA JULGADA INTRODUZIDA PELO CÓDIGO DE PROCESSO CIVIL DE 2015}

Os juristas que idealizaram o CPC/15, ao dispor acerca da formação da coisa julgada sobre decisões judiciais irrecorríveis ou com seu prazo recursal já expirado, optaram por, em linhas gerais, manter grande parte da regulamentação trazida pelo diploma processual predecessor, primando, contudo, por aprimorar a redação dos dispositivos legais, com vistas a tornar mais clara e homogênea sua interpretação pela comunidade jurídica. Porém, trouxeram relevante inovação no que concerne à possibilidade de formação de coisa julgada sobre questões prejudiciais decididas incidentalmente. A novidade só se aplicaria às questões prejudiciais incidentais, na medida em que sobre as questões prejudiciais principais já se formaria naturalmente a coisa julgada, por integrarem o objeto da lide, ou seja, por traduzirem um dos pedidos nesta formulados (DIDIER JR. et al, 2016a, p.554).

Sob a sistemática do $\mathrm{CPC} / 73$, como regra, não faria coisa julgada "a apreciação de questão prejudicial, decidida incidentalmente no processo" (art.469, III, CPC/73). Como consequência, caso desejassem as partes que, sobre determinada questão prejudicial, se formasse coisa julgada, far-se-ia necessário que a tornassem questão principal - e não meramente incidental -, o que se dava por intermédio da ação declaratória incidental:

\footnotetext{
A ação declaratória incidental (arts.5 $5^{\circ}, 325$ e 470 do CPC-1973) tinha por utilidade transformar a análise da questão prejudicial controvertida. Posta, inicialmente, como simples fundamento do pedido, a questão prejudicial seria resolvida incidenter tantum e, na forma do inciso III do art.469 do CPC-1973, não ficaria acobertada pela coisa julgada. Proposta a ação declaratória incidental, a questão prejudicial passava a ser objeto de resolução principaliter, compondo o thema decidendum; a solução que o magistrado lhe desse ficaria acobertada pela coisa julgada (art.470 do CPC-1973). Com ação declaratória incidental, a análise da questão prejudicial mudava: ela deixava de ser simples fundamento e passava a ser objeto da decisão do magistrado. (DIDIER JR. et al, 2016a, p.554)
}

Consoante o art.470 do CPC/73, para que a análise da questão prejudicial produzisse coisa julgada, não bastaria que a parte o requeresse via ação declaratória incidental $\left(\operatorname{arts.} 5^{\circ} \mathrm{e}\right.$ 325 do CPC/73), mas também que o juiz fosse competente em razão da matéria e que a questão constituísse pressuposto necessário ao julgamento da lide.

O CPC/15, a seu turno, rompe com essa sistemática, eliminando a necessidade de requerimento das partes: prevê a possibilidade de formação de coisa julgada sobre questões prejudiciais decididas incidentalmente, sem que, para tanto, essas tivessem que se tornar questão principal via ação declaratória incidental ou que fosse necessário o requerimento das partes ou a declaração do órgão julgador no sentido de se conceder esse efeito. Pelo contrário, 
a formação da coisa julgada "é efeito que decorre automaticamente da lei: não depende de um ‘dizer’ do órgão julgador ('faça-se coisa julgada!') ou de pedido da parte ('pede-se que essa decisão se torne indiscutível pela coisa julgada!')" (DIDIER JR. et al, 2016a, p.548).

É a redação do art.503 do CPC/15:

Art.503. A decisão que julgar total ou parcialmente o mérito tem força de lei nos limites da questão principal expressamente decidida.

$\S 1^{\circ} \mathrm{O}$ disposto no caput aplica-se à resolução de questão prejudicial, decidida expressa e incidentemente no processo, se:

I - dessa resolução depender o julgamento do mérito;

II - a seu respeito tiver havido contraditório prévio e efetivo, não se aplicando no caso de revelia;

III - o juízo tiver competência em razão da matéria e da pessoa para resolvêla como questão principal.

$\S 2^{\circ}$ A hipótese do $\S 1^{\circ}$ não se aplica se no processo houver restrições probatórias ou limitações à cognição que impeçam o aprofundamento da análise da questão prejudicial. (BRASIL, Lei n. ${ }^{\circ}$ 13.105, de 2015)

A partir da análise de referido dispositivo, torna-se claro que, como requisitos à formação de coisa julgada sobre a decisão acerca de questão prejudicial incidental, manteve o CPC/15 a necessidade de que dessa resolução dependesse o julgamento do mérito e de que o juízo fosse competente em razão da matéria para decidi-lo. Vale dizer, portanto, que questões meramente processuais ou que constituíssem obiter dicta não estariam contempladas por essa possibilidade (DIDIER JR. et al, 2016a, p.550) da mesma forma que as questões cujo magistrado não pudesse decidir também como principais.

Ademais, acrescentou o CPC/15 a necessidade de que, em relação a elas, tenha havido prévio e efetivo contraditório, e de que o juízo fosse também competente em razão da pessoa para julgá-las. Trata-se de requisitos, contudo, que, mesmo se ausentes no dispositivo legal, poderiam ser inferidos com semelhante exigibilidade, uma vez que o primeiro (prévio e efetivo contraditório) traduziria garantia constitucional, e o segundo (competência em razão da pessoa) decorreria da interpretação sistêmica do diploma processual civil.

No que concerne ao contraditório, vale ressaltar a vedação legal de formação de coisa julgada sobre questões prejudiciais decididas incidentalmente, caso o procedimento ao qual se sujeitar a ação judicial contiver restrições probatórias ou limitações à cognição que impeçam o aprofundamento da análise acerca da referida questão (art.503, §2, $\mathrm{CPC} / 15$ ). É o que se verifica, por exemplo, em ações que não admitem dilação probatória, tais como o mandado de segurança (DIDIER JR. et al, 2016a, p.552). 


\section{AÇÕES COLETIVAS E CONTROLE DIFUSO DE CONSTITUCIONALIDADE: PONDERAÇÕES À LUZ DA NOVA SISTEMÁTICA DE COISA JULGADA INTRODUZIDA PELO CÓDIGO DE PROCESSO CIVIL DE 2015}

\section{A IRRADIAÇÃO ERGA OMNES OU ULTRA PARTES DOS EFEITOS DA COISA JULGADA NAS AÇÕES COLETIVAS}

No âmbito do sistema integrado de tutela processual coletiva, contudo, a regulamentação da coisa julgada não segue lógica idêntica àquela prevista para as ações individuais: adequa-se o instituto ao devido processo legal coletivo e aplica-se o CPC/15 apenas de forma subsidiária, no que não for incompatível com a processualística coletiva.

Ao regulamentar o instituto da coisa julgada para as ações individuais, o CPC/15, em seu art.506, dispõe que essa imutabilidade das decisões de mérito só se aplicaria "às partes entre as quais é dada, não prejudicando terceiros", vale dizer, de forma inter partes, ou seja, às partes que integraram a relação jurídico-processual.

Entretanto, referida restrição aos efeitos da coisa julgada culminaria por esvaziar o escopo das ações coletivas, na medida em que é da essência destas que o interesse transindividual ou individual homogêneo seja tutelado em juízo por legitimados autônomos ou substitutos processuais, respectivamente ( $c f$. THIBAU, 2003). Vale dizer, portanto, que, nas ações coletivas, os membros da coletividade diretamente interessada, via de regra, não integrariam a relação jurídico-processual na condição de partes, de tal forma que, caso os efeitos da coisa julgada se aplicassem inter partes, dificilmente alcançariam aqueles cujos interesses estariam sendo tutelados nestas ações ${ }^{4}$.

Com vistas a se adequar a regulação da coisa julgada ao devido processo legal coletivo, tornou-se possível a esta, em ações coletivas, irradiar efeitos para além dos limites subjetivos da lide, para alcançar os membros da coletividade cujos interesses estariam sendo tutelados e que não teriam integrado nenhum dos polos processuais. No que tange aos direitos difusos e coletivos em sentido estrito, a própria indivisibilidade do objeto passou a exigir a extensão dos efeitos da coisa julgada para além dos limites da lide. Da mesma forma, "houve uma releitura da sistemática da coisa julgada, de modo a mitigar sua formação conforme a suficiência da prova produzida" (DONIZETTI, 2010, p.356).

\footnotetext{
${ }^{4}$ Alguns doutrinadores, por outro lado, consideram que, no plano de ações coletivas, falar-se-ia somente em substituição processual e que, em decorrência disso, os membros da coletividade interessada traduziriam, senão, partes no sentido material: "Na realidade, inexiste razão para se dizer que, no plano coletivo, a coisa julgada não é inter partes. Isso porque, havendo substituição processual da coletividade por entidade ou pessoa designada legalmente para esse fim, a vinculação da coletividade substituída à coisa julgada é natural, pois não se trata de terceiro, mas sim parte no sentido material" (DONIZETTI et al, 2010, p.357).
} 
Em diversos ordenamentos jurídicos estrangeiros, a irradiação dos efeitos da coisa julgada aos membros da coletividade interessada se dá por intermédio dos mecanismos do opt in ou do opt out, conforme se exija do membro da coletividade manifestar seu desejo expresso de se vincular ao resultado da ação coletiva ou requerer sua exclusão desta, respectivamente. No caso brasileiro, a seu turno, as dificuldades ainda existentes ao pleno acesso à justiça e à informação a toda a população acerca da existência e do teor de ações coletivas, tornaria irrazoável atribuir aos membros da coletividade o ônus de decidir, e manifestar nos autos essa decisão, de vincular-se ou não à coisa julgada porventura a ser formada nas ações coletivas.

Completamente diversa é a opção dos países ibero-americanos. Levando em consideração a falta de informação e de conscientização a respeito de seus direitos de grandes parcelas da população, a dificuldade de comunicação, a distância, e a precariedade dos meios de transporte, a dificuldade de acesso à justiça, as barreiras para a contratação de um advogado, esses países (com exceção da Colômbia e de Portugal) descartam seja o opt in, seja o opt out, seguindo linha completamente diferente da supra traçada: a linha da coisa julgada secundum eventum litis, só para beneficiar, mas não para prejudicar os membros do grupo. (GRINOVER, 2011, p.240)

O modelo de irradiação dos efeitos da coisa julgada adotado pelo sistema integrado brasileiro de tutela processual coletiva, portanto, visa alcançar a todos os membros da coletividade afetada (independentemente de manifestarem seu desejo de se vincularem ou desvincularem do resultado da ação) em relação à indivisibilidade do objeto da demanda, sem, contudo, importar-lhes prejuízo, como regra, à sua esfera individual. Neste sentido, falar-se em coisa julgada secundum eventum litis (cf. GRINOVER, 2014a, pp.388-389).

Paralelamente, haja vista o fato de serem estes direitos tutelados em juízo por entes intermediários, optou o legislador do Código de Defesa do Consumidor (CDC/90) por não atribuir força de coisa julgada material às decisões de improcedência por insuficiência de provas em ações coletivas em tutela de direitos difusos e coletivos em sentido estrito - coisa julgada secundum eventum probationis. O objetivo foi prevenir que situações de colheita insuficiente de provas para instrução da ação coletiva, ou ainda, de possível conluio entre o ente intermediário e a parte ré, pudessem prejudicar a coletividade interessada (RODRIGUES, 2014, p.971). Como consequência, decisões de improcedência por insuficiência de provas, em ações em tutela de direitos difusos e coletivos em sentido estrito, produziriam apenas coisa julgada formal, não impedindo o ajuizamento de ação coletiva com fundamento idêntico - desde que lastreada em nova prova. É o que se extrai da redação do art.103 do CDC/90: 


\section{AÇÕES COLETIVAS E CONTROLE DIFUSO DE CONSTITUCIONALIDADE: PONDERAÇÕES À LUZ DA NOVA SISTEMÁTICA DE COISA JULGADA INTRODUZIDA PELO CÓDIGO DE PROCESSO CIVIL DE 2015}

Art.103. Nas ações coletivas de que trata este código, a sentença fará coisa julgada:

I - erga omnes, exceto se o pedido for julgado improcedente por insuficiência de provas, hipótese em que qualquer legitimado poderá intentar outra ação, com idêntico fundamento valendo-se de nova prova, na hipótese do inciso I do parágrafo único do art. 81;

II - ultra partes, mas limitadamente ao grupo, categoria ou classe, salvo improcedência por insuficiência de provas, nos termos do inciso anterior, quando se tratar da hipótese prevista no inciso II do parágrafo único do art. 81 ;

III - erga omnes, apenas no caso de procedência do pedido, para beneficiar todas as vítimas e seus sucessores, na hipótese do inciso III do parágrafo único do art. 81.

$\S 1^{\circ}$ Os efeitos da coisa julgada previstos nos incisos I e II não prejudicarão interesses e direitos individuais dos integrantes da coletividade, do grupo, categoria ou classe.

$\S 2^{\circ} \mathrm{Na}$ hipótese prevista no inciso III, em caso de improcedência do pedido, os interessados que não tiverem intervindo no processo como litisconsortes poderão propor ação de indenização a título individual.

$\S 3^{\circ}$ Os efeitos da coisa julgada de que cuida o art. 16, combinado com o art. 13 da Lei $\mathrm{n}^{\circ} 7.347$, de 24 de julho de 1985, não prejudicarão as ações de indenização por danos pessoalmente sofridos, propostas individualmente ou na forma prevista neste código, mas, se procedente o pedido, beneficiarão as vítimas e seus sucessores, que poderão proceder à liquidação e à execução, nos termos dos arts. 96 a 99.

$\S 4^{\circ}$ Aplica-se o disposto no parágrafo anterior à sentença penal condenatória. (BRASIL. Lei n. ${ }^{\circ} 8.078$, de 1990)

É inequívoco, apesar de não o mencionar diretamente o dispositivo, que, independentemente da espécie de direito transindividual ou individual homogêneo que tutele a ação coletiva, tanto nos casos de sentença de procedência, como de improcedência - exceto por insuficiência de provas -, formar-se-á coisa julgada material, a inviabilizar o ajuizamento de nova ação coletiva com idêntico fundamento. O que ressalva o texto legal, contudo, é que a irradiação dos efeitos dessa coisa julgada material, de forma erga omnes no caso de direitos difusos e individuais homogêneos, ou ultra partes no caso de direitos coletivos em sentido estrito, não prejudicará interesses individuais dos membros da coletividade.

No que concerne a direitos individuais homogêneos (individuais por essência e tuteláveis coletivamente em razão de sua homogeneidade), tem-se que a coisa julgada formada sobre a sentença de procedência da ação coletiva encontra-se apta a irradiar seus efeitos de forma erga omnes, em benefício dos membros da coletividade, ao passo que a sentença de improcedência, apesar de produzir coisa julgada material no âmbito coletivo (obstando a propositura de nova ação coletiva com idêntico fundamento), não impede que sejam ajuizadas as ações individuais respectivas. A exceção é o caso dos indivíduos que, por força do art.94 do 
CDC/90, tenham atuado como assistentes litisconsorciais do ente intermediário na ação coletiva, os quais se encontrarão vinculados pela coisa julgada material produzida nesta, seja em caso de procedência ou de improcedência.

Já em relação às ações coletivas em defesa de interesses difusos ou coletivos em sentido estrito, tem-se que a irradiação dos efeitos da coisa julgada de forma erga omnes se dá em casos de procedência ou improcedência (exceto por insuficiência de provas) dos pedidos, no que tange ao objeto indivisível da demanda coletiva ${ }^{5}$. Entretanto, não importará prejuízos a eventuais interesses individuais porventura relacionados à pretensão coletiva, os quais ainda poderão ser pleiteados pela via de ações individuais:

Ou seja, a coisa julgada, no plano coletivo, atua erga omnes, tanto em caso de acolhimento como de rejeição da demanda, impedindo que novo processo coletivo seja intentado por qualquer legitimado. Mas, no plano das pretensões individuais, a coisa julgada favorável pode ser imediatamente aproveitada, passando-se à liquidação e execução da sentença; enquanto a coisa julgada desfavorável não impede ações individuais, a título pessoal, dos membros do grupo. (GRINOVER, 2011, p.241)

\section{COISA JULGADA E CONTROLE DIFUSO DE CONSTITUCIONALIDADE EM AÇÕES COLETIVAS}

Apesar de amplamente admitido o controle difuso de constitucionalidade em lides intersubjetivas relativas a direitos individuais, é historicamente controvertida sua admissibilidade em ações coletivas em tutela de direitos transindividuais e individuais homogêneos, em razão da já explicitada disciplina da coisa julgada, peculiar nestas ações.

É inerente ao controle difuso de constitucionalidade que seus efeitos se apliquem exclusivamente às partes que litigam no processo judicial em que é realizado. Em outras palavras, em sede de controle difuso de constitucionalidade, a eventual declaração de inconstitucionalidade de determinada norma ou interpretação normativa não se encontra apta a retirá-la do ordenamento jurídico ou modificar sua interpretação. Pelo contrário, os efeitos dessa declaração apenas serão sentidos pelas partes litigantes, e tão somente enquanto pressuposto (questão prejudicial) à decisão da matéria principal veiculada nos autos do processo. Portanto,

\footnotetext{
5 “Com relação à demanda que envolve a tutela de direitos difusos e coletivos, indivisíveis por natureza, a coisa julgada não pode senão atuar erga omnes. A satisfação do interesse de um dos membros da coletividade significa inelutavelmente a satisfação dos interesses de todos os outros; assim como a negação do interesse de um indica a mesma negação para todos os outros" (GRINOVER, 2011, p.237).
} 


\section{AÇÕES COLETIVAS E CONTROLE DIFUSO DE CONSTITUCIONALIDADE: PONDERAÇÕES À LUZ DA NOVA SISTEMÁTICA DE COISA JULGADA INTRODUZIDA PELO CÓDIGO DE PROCESSO CIVIL DE 2015}

pode-se dizer que é da essência do controle difuso de constitucionalidade a irradiação de seus efeitos de forma inter partes.

Contudo, em ações coletivas, a coisa julgada produzida - conforme o resultado da lide - irradiará seus efeitos para além dos limites subjetivos da ação, de forma erga omnes ou ultra partes, sob pena de, não o fazendo, esvaziar-se o escopo de referidos remédios processuais. Diante disso, passou-se a questionar se seria compatível a disciplina do controle difuso de constitucionalidade, restrito aos limites subjetivos da lide, e a sistemática das ações coletivas, que irradiariam os efeitos da coisa julgada em si produzida.

Sob a vigência do CPC/73, encontrou-se resposta definitivamente positiva ao aludido questionamento, sob o fundamento de que, analisada a constitucionalidade da lei ou ato normativo de forma prejudicial incidental ao mérito da ação coletiva, não se formaria coisa julgada material sobre este aspecto da decisão e, como consequência, não se haveria que cogitar a possibilidade de irradiação dos efeitos dessa determinação. Entretanto, como já abordado, trouxe o CPC/15 nova disposição acerca da coisa julgada, aplicável subsidiariamente ao sistema integrado de tutela processual coletiva, de tal forma que estas respostas ofertadas pelo CPC/73 passaram a merecer reapreciação.

\subsection{O Controle Difuso de Constitucionalidade em Ações Coletivas sob a vigência do Código de Processo Civil de 1973}

Consoante já explanado em tópico anterior, sob a vigência do CPC/73, como regra, não se formava coisa julgada sobre a questão prejudicial decidida incidentalmente, exceto se, pela via da ação declaratória incidental, essa passasse a ocupar o papel de questão prejudicial principal, e, cumulativamente, fosse pressuposto essencial ao julgamento do mérito e julgada por juízo competente em razão da matéria.

Assim sendo, e considerando-se que o controle de constitucionalidade, para poder ser realizado de forma difusa pelos mais diversos juízos e tribunais do país, somente poderia se dar enquanto questão prejudicial ao julgamento da lide, analisada de forma incidental, a lógica conduz à conclusão de que não estaria este controle difuso, ao menos em regra, suscetível à formação de coisa julgada:

Se a declaração da inconstitucionalidade ocorre incidentemente, pela acolhida da questão prejudicial que é fundamento do pedido ou da defesa, a decisão 
não tem autoridade de coisa julgada, nem se projeta - mesmo inter partes fora do processo no qual foi proferida. (GRINOVER, 2014b, p.487)

Logo, em ações coletivas, independentemente do resultado da lide, os efeitos porventura incidentes sobre a coisa julgada não alcançariam a resolução do controle difuso de constitucionalidade, por se tratar de questão prejudicial incidental.

Referida compreensão foi de fundamental importância para que se consolidassem a jurisprudência e a doutrina no sentido de admitirem a realização de controle difuso de constitucionalidade no âmbito de ações coletivas. As limitações à formação de coisa julgada sobre questões decididas incidentalmente assegurariam que os efeitos irradiantes da coisa julgada formada nestas ações não alcançassem a decisão em controle difuso de constitucionalidade, o que, pelo contrário, poderia culminar por, inadequadamente, produzir repercussões análogas às do controle concentrado, sem a observância do devido processo legal e constitucional para tanto.

Diversamente, entretanto, a doutrina de DONIZETTI et al (2010, pp.187-189), apesar de alinhar-se às ponderações acima expostas, aponta que existiria entendimento minoritário no sentido do descabimento da declaração incidental de inconstitucionalidade de normas no bojo de ações coletivas, sob a vigência do $\mathrm{CPC} / 73$. Referida compreensão se lastrearia no fundamento de que "os efeitos erga omnes da decisão final equivaleriam aos da ação direta de inconstitucionalidade ou da ação declaratória de constitucionalidade (processo coletivo objetivo)" (DONIZETTI et al, 2010, p.188).

\subsection{A Nova Disciplina sobre a Coisa Julgada e seus Reflexos no Controle Difuso de Constitucionalidade em Ações Coletivas}

Percebe-se, assim, que, sob a vigência do CPC/73, o principal argumento que estaria a justificar a admissibilidade da realização de controle difuso de constitucionalidade no âmbito de ações coletivas seria a vedação da norma processual civil comum à formação de coisa julgada sobre as questões prejudiciais decididas incidentalmente. Como consequência, não se poderia falar em atribuição de efeitos erga omnes ou ultra partes sobre a decisão acerca da (in)constitucionalidade, o que impediria que as ações coletivas do direito processual coletivo comum viessem a ser utilizadas como substitutivos às ações integrantes do direito processual coletivo especial, nos termos da classificação de ALMEIDA (2003). 


\section{AÇÕES COLETIVAS E CONTROLE DIFUSO DE CONSTITUCIONALIDADE: PONDERAÇÕES À LUZ DA NOVA SISTEMÁTICA DE COISA JULGADA INTRODUZIDA PELO CÓDIGO DE PROCESSO CIVIL DE 2015}

$\mathrm{O} \mathrm{CPC} / 15$, entretanto, modificou essa lógica, no sentido de estender às questões prejudiciais decididas incidentalmente a possibilidade de formação de coisa julgada, o que poderia conduzir a uma primeira compreensão de que teria se esvaziado esse principal fundamento a lastrear o entendimento pela admissibilidade do controle difuso de constitucionalidade no bojo de ações coletivas. Todavia, referida análise não deve desconsiderar as condicionantes trazidas pelo art.503, $\S 1^{\circ}$, do $\mathrm{CPC} / 15$, à extensão da coisa julgada às questões decididas incidentalmente:

Art.503. [...] $\$ 1^{\circ} \mathrm{O}$ disposto no caput aplica-se à resolução de questão prejudicial, decidida expressa e incidentemente no processo, se:

I - dessa resolução depender o julgamento do mérito;

II - a seu respeito tiver havido contraditório prévio e efetivo, não se aplicando no caso de revelia;

III - o juízo tiver competência em razão da matéria e da pessoa para resolvêla como questão principal. (BRASIL, Lei n. ${ }^{\circ} 13.105$, de 2015)

Passar-se-á, portanto, a analisa-las uma a uma, considerando-se hipoteticamente que a questão prejudicial a ser decidida incidentalmente consistiria na constitucionalidade de lei ou ato normativo (controle difuso), no âmbito de ação coletiva.

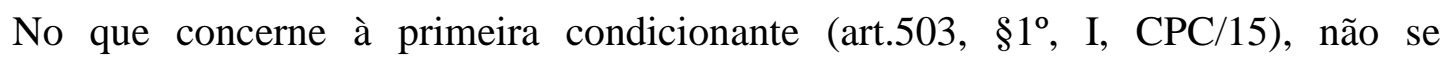
vislumbram quaisquer óbices ao seu preenchimento, na medida em que somente se justificaria o controle difuso de constitucionalidade (seja no âmbito de ações coletivas, seja de ações individuais), caso esse constituísse pressuposto indispensável ao julgamento meritório da questão principal sobre a qual versar a lide. No tocante a este ponto, vale rememorar que o controle difuso é, por essência, realizado à luz do caso concreto, ou seja, consiste na avaliação da validade da norma que teria fundamentado o fato jurídico, ação ou omissão que compõem o objeto principal da lide, o que, inequivocamente interferiria na apuração da eventual consequência jurídica a este fato ou ato.

Por sua vez, em relação ao preenchimento da segunda condicionante (art.503, § $1^{\circ}$, II, CPC/15), a análise pode trazer consigo maior complexidade, na medida em que, segundo alguns autores, a plenitude do contraditório prévio não dependeria apenas de se oportunizar a ambas as partes o exercício de seu direito de manifestação. Conforme o entendimento esposado por DIDIER JR. et al (2016a, p.551), somente se poderia cogitar a plenitude de contraditório caso a questão prejudicial fosse suscitada e fundamentada por ente legitimado a apresenta-la enquanto questão principal: 
O pressuposto do contraditório efetivo impõe, também, que a questão prejudicial incidental tenha sido posta à apreciação jurisdicional por alguém legitimado a apresenta-la como questão principal. Um exemplo: a constitucionalidade de uma lei pode ser suscitada como questão incidental por qualquer sujeito, no controle difuso, mas apenas aqueles previstos no art.103 da CF/1988 podem discuti-la como questão principal, no controle concentrado. É por isso que, reconhecida a inconstitucionalidade de uma lei em controle difuso, mesmo que pelo STF (no julgamento do recurso extraordinário, p. ex.), não haverá a extensão da coisa julgada a essa prejudicial, em razão da ausência de contraditório efetivo em torno da questão, que pressupõe a provocação e a participação de algum dos legitimados do art.103 da CF/1988. Se fosse diferente, o $\S 1^{\circ}$ do art.503 do CPC poderia ser utilizado como instrumento de fraude à Constituição. (DIDIER JR. et al, 2016a, p.551)

Entretanto, trasladando-se o mencionado entendimento doutrinário às ações coletivas, verifica-se que, caso a inconstitucionalidade da norma seja suscitada como questão incidental pelo ente intermediário que atua em juízo em prol dos interesses da coletividade, tem-se que não seria impossível que este ente fosse também legitimado a apresentar a inconstitucionalidade como questão principal (porém, em ações de controle concentrado de constitucionalidade). É o caso, por exemplo, dos partidos políticos com representação no Congresso Nacional e das confederações sindicais ou entidades de classe de âmbito nacional, todos estes legitimados ativos às ações de controle concentrado (art.103, VIII e IX, da CR/88), os quais poderiam se enquadrar também na categoria das "associações legalmente constituídas há pelo menos um ano" e que possuiriam como fim institucional a defesa de interesses transindividuais ou individuais homogêneos, estas legitimadas à propositura de ações coletivas, nos termos dos arts. $5^{\circ}$, da Lei n. $.^{\circ} 7.347 / 1985$, e 82, do CDC/90.

Em casos tais, não haveria dúvidas quanto à possibilidade de preenchimento também da segunda condicionante à formação de coisa julgada sobre questões prejudiciais incidentais, trazida pelo parágrafo primeiro do art.503 do CPC/15.

Por fim, quanto à terceira condicionante (art.503, §1 ${ }^{\circ}$, III, CPC/15), faz-se mister reconhecer que seria mais dificultoso o seu preenchimento no que concerne à decisão prejudicial incidental acerca de controle difuso de constitucionalidade, ainda que no âmbito de ações coletivas. Impõe o legislador que, para que se forme coisa julgada sobre as questões prejudiciais decididas incidentalmente, o juízo a julga-las nestas circunstâncias precisaria ser também competente em razão da matéria e da pessoa para fazê-lo enquanto questão principal.

Como já elucidado, o julgamento do controle de constitucionalidade como questão principal, só poderia se dar em sede de controle concentrado, mediante os procedimentos 


\section{AÇÕES COLETIVAS E CONTROLE DIFUSO DE CONSTITUCIONALIDADE: PONDERAÇÕES À LUZ DA NOVA SISTEMÁTICA DE COISA JULGADA INTRODUZIDA PELO CÓDIGO DE PROCESSO CIVIL DE 2015}

próprios do processo coletivo especial (ALMEIDA, 2003), perante Corte definida para tanto. Em se tratando de controle à luz da CR/88, esta Corte seria o STF, ao passo que o controle de constitucionalidade de leis municipais ou estaduais à luz das Constituições Estaduais seria realizado perante os Tribunais de Justiça dos Estados (art.125, §2, $\mathrm{CR} / 88$ ).

Exatamente em razão desta condicionante imposta pelo CPC/15 à formação de coisa julgada sobre questões prejudiciais incidentais, entendeu a doutrina de DIDIER JR. et al (2016b) pela continuidade da possibilidade de controle difuso em ações coletivas:

A solução não se altera com o CPC-2015, que permitiu a extensão da coisa julgada às questões prejudiciais incidentais (art.503, $\left.\S 1^{\circ}, \mathrm{CPC}\right)$. Isso porque um dos impedimentos a essa extensão é exatamente a ausência de competência, em razão da matéria, para conhecer da questão como principal (art.503, $\S 1^{\circ}$, III, CPC). O órgão julgador não tem competência para decidir a inconstitucionalidade da lei como questão principal; assim, a coisa julgada não se estende à solução dessa questão quando posta incidenter tantum. (DIDIER JR. et al, 2016b, pp.332-333)

Tem-se, portanto, que compreenderam os doutrinadores que, em sede de controle difuso de constitucionalidade em ações coletivas, não se poderia falar em competência do órgão julgador para apreciação da questão prejudicial como questão principal, de forma que não se formaria coisa julgada sobre esta decisão (ainda que nos termos do CPC/15) e, tão logo, não haveria possibilidade de irradiação erga omnes ou ultra partes dos efeitos desta.

Entretanto, é possível vislumbrar-se hipóteses em que, no âmbito de ações coletivas, seja realizado controle difuso de constitucionalidade de lei municipal ou estadual, em relação à Constituição Estadual, em sede recursal, no âmbito do respectivo Tribunal de Justiça. Ou ainda, hipóteses de controle difuso de constitucionalidade de leis ou atos normativos em relação à CR/88, em sede de recurso extraordinário, perante o próprio STF. Em ambos os casos, ao menos em análise perfunctória, seria possível considerar-se o preenchimento do terceiro requisito do parágrafo primeiro do art.503 do CPC/15: o juízo a apreciar a constitucionalidade da lei, em caráter incidental (em sede recursal, no bojo de ação coletiva, integrante do direito processual coletivo comum), seria também aquele porventura competente para esta apreciação em sede de controle concentrado, como questão principal.

Em outras palavras, conclui-se que seria possível antever hipóteses de controle difuso de constitucionalidade, em sede de ações coletivas, nas quais a resolução dessa questão prejudicial incidentalmente preencheria as três condicionantes do CPC/15 para que passasse a ser abarcada pela formação da coisa julgada. 
Entretanto, cumpre reconhecer que, em casos tais, ainda que porventura fossem preenchidas simultaneamente as três condicionantes, e que o controle difuso se desse em ação coletiva, não se poderia cogitar a irradiação erga omnes ou ultra partes dos efeitos dessa decisão, sob pena de se ofender a ordem constitucional. Ocorre que a $\mathrm{CR} / 88$, atenta à presunção de validade das leis e atos normativos, e visando preservar a segurança jurídica dos jurisdicionados (que, como regra, pautam suas ações e omissões nas normas vigentes), estabeleceu que as decisões definitivas de mérito acerca da constitucionalidade ou inconstitucionalidade de normas possuiriam eficácia contra todos e efeito vinculante, porém desde que proferidas no âmbito de ADI's e ADC's, pelo STF (art.102, §2º CR/88).

E com o fito de garantir o aspecto democrático do procedimento dessas ações em controle concentrado, determinou rol peculiar de entes que poderiam propô-las, estabeleceu que, em casos de ADI, mereceria a lei ou ato normativo também sua respectiva defesa a ser exercida pelo Advogado-Geral da União, e vinculou a ação ao parecer do Procurador Geral da República. Em outras palavras, apesar de não haver tecnicamente lide intersubjetiva no âmbito de ações em controle concentrado, cuidou a CR/88 por equipara-las às ações que possuem, estabelecendo espaço para o contraditório e determinando a fiscalização do Ministério Público (no caso, por intermédio do Procurador Geral da República).

Tem-se, portanto, que o rito aplicável às ações em controle concentrado não seria equiparável àquele das ações coletivas, o que conduz à conclusão de que estas últimas não poderiam ser utilizadas como via alternativa às primeiras, com o intuito de se obter o mesmo resultado com igual segurança jurídica e representatividade dos jurisdicionados.

Por mais amplo que seja o alcance subjetivo da questão principal discutida em uma ação coletiva, o controle difuso de constitucionalidade nesta realizado se daria, por essência, sempre à luz dessa questão principal, ou seja, desse caso concreto, não se revestindo, portanto, da suficiente amplitude e abstração necessárias à apuração democrática de constitucionalidade de norma que pudesse ser oponível a todos os jurisdicionados.

E ainda que, nas ações coletivas (integrantes do direito processual coletivo comum, classificado por ALMEIDA, 2003), os entes intermediários possuam legitimidade para tutelar em juízo os interesses da coletividade interessada, não restam dúvidas de que não é conferida a estes entes a legitimidade para defender a constitucionalidade ou inconstitucionalidade de determinada lei ou ato normativo, em abstrato, com potenciais efeitos para todos os jurisdicionados (e não apenas para os membros da coletividade). 


\section{AÇÕES COLETIVAS E CONTROLE DIFUSO DE CONSTITUCIONALIDADE: PONDERAÇÕES À LUZ DA NOVA SISTEMÁTICA DE COISA JULGADA INTRODUZIDA PELO CÓDIGO DE PROCESSO CIVIL DE 2015}

Ademais, não oferecem as ações coletivas o adequado contraditório acerca da arguição de inconstitucionalidade, para fins de definitiva manutenção ou retirada da norma do ordenamento: nas ações coletivas, apenas as partes litigantes se manifestarão, ao passo que, para se avaliar democraticamente a constitucionalidade em abstrato de uma lei ou ato normativo estabelece a CR/88 a necessidade de defesa da validade desta lei pelo Advogado Geral da União e de parecer do Procurador Geral da República.

A adoção de procedimento mais rígido para tanto se justifica, inclusive, pelo fato de que referidas leis em análise seriam fruto da vontade de representantes eleitos democraticamente para ocupar os cargos eletivos do Poder Legislativo. Admitir-se, portanto, o eventual afastamento dessas normas legisladas, por intermédio de instrumentos processuais inadequados e diversos daqueles previstos na $\mathrm{CR} / 88$ para tanto, violaria flagrantemente, assim, o princípio democrático que rege o Estado Democrático de Direito.

\section{CONCLUSÃO}

Conclui-se que, apesar de ter inovado o CPC/15 em relação ao CPC/73, no que concerne à disciplina da coisa julgada, permitindo sua formação sobre questões prejudiciais decididas incidentalmente, não se poderia considerar que referida norma estaria apta a possibilitar a formação de coisa julgada erga omnes ou ultra partes no caso de decisão em controle difuso de constitucionalidade no âmbito de ações coletivas.

Assim, ainda que se preencham, em referidos casos, todos os requisitos do art.503, $\S 1^{\circ}$, do CPC/15, a formação de coisa julgada com tais efeitos em relação ao controle difuso de constitucionalidade importaria flagrante afronta aos princípios que norteiam o Estado Democrático de Direito, haja vista que viabilizaria que fosse definitivamente retirada determinada norma do ordenamento jurídico, ou ainda declarada sua constitucionalidade em caráter definitivo, sem a observância do devido processo legal e constitucional (vale dizer, ações em controle concentrado de constitucionalidade).

Não se está a dizer, contudo, que passaria a ser vedado o controle difuso de constitucionalidade em ações coletivas. Pelo contrário, não se vislumbra qualquer prejuízo à realização desse controle, desde que, produzida porventura a coisa julgada sobre a decisão a seu respeito, não se aplique sobre ela os efeitos erga omnes ou ultra partes, sob pena de se violar a ordem constitucional. Em outras palavras, propõe-se que se proceda a uma 
interpretação conjunta do art.503, $\S 1^{\circ}$, do CPC/15 e do art.103, CDC/90, à luz da CR/88, para fins de se afastar a irradiação de efeitos da eventual coisa julgada produzida em controle difuso de constitucionalidade em ações coletivas.

\section{REFERÊNCIAS BIBLIOGRÁFICAS}

ALMEIDA, Gregório Assagra de. Direito Processual Coletivo Brasileiro: Um Novo Ramo do Direito Processual (princípios, regras interpretativas e a problemática da sua interpretação e aplicação). São Paulo: Saraiva, 2003.

BRASIL. Lei n. ${ }^{\circ}$ 5.869, de 11 de janeiro de 1973 [Revogada pela Lei n. ${ }^{\circ} 13.105$, de 2015]. Institui o Código de Processo Civil. Disponível em: http://www.planalto.gov.br/ccivil_03/leis/L5869impressao.htm - Acesso em 15.08.2017.

BRASIL. Lei n. ${ }^{\circ}$ 7.347, de 24 de julho 1985. Disciplina a ação civil pública de responsabilidade por danos causados ao meio-ambiente, ao consumidor, a bens e direitos de valor artístico, estético, histórico, turístico e paisagístico (VETADO) e dá outras providências. Disponível em: http://www.planalto.gov.br/ccivil_03/leis/L7347orig.htm - Acesso em 20.08.2017.

BRASIL. Constituição da República Federativa do Brasil de 1988. Promulgada em 05 de outubro de 1988. Disponível em: http://www.planalto.gov.br/ccivil_03/constituicao/ constituicaocompilado.htm - Acesso em 19.08.2017.

BRASIL. Lei n. ${ }^{\circ} 8.078$, de 11 de setembro de 1990. Dispõe sobre a proteção do consumidor e dá outras providências. Disponível em: http://www.planalto.gov.br/ccivil_03/leis/L8078.htm Acesso em 15.08.2017.

BRASIL. Lei n. ${ }^{\circ} 9.868$, de 10 de novembro de 1999. Dispõe sobre o processo e julgamento da ação direta de inconstitucionalidade e da ação declaratória de constitucionalidade perante o Supremo Tribunal Federal. Disponível em: http://www.planalto.gov.br/ccivil_03/leis/L9868.htm - Acesso em: 19.08.2017.

BRASIL. Lei n. ${ }^{\circ} 13.105$, de 16 de março de 2015. Código de Processo Civil. Disponível em: http://www.planalto.gov.br/ccivil_03/_ato2015-2018/2015/lei/113105.htm - Acesso em 15.08.2017.

DIDIER JR., Fredie; BRAGA, Paula Sarno; OLIVEIRA, Rafael Alexandria de. Curso de Direito Processual Civil: Teoria da Prova, Direito Probatório, Ações Probatórias, Decisão, Precedente, Coisa Julgada e Antecipação dos Efeitos da Tutela. 11.ed.rev.ampl.e atual. Salvador: Ed. JusPodivm, 2016a.

DIDIER JR., Fredie; ZANETI JR., Hermes. Curso de Direito Processual Civil: Processo Coletivo. 10.ed.rev.ampl.e atual. Salvador: Ed. JusPodivm, $2016 \mathrm{~b}$. 


\section{AÇÕES COLETIVAS E CONTROLE DIFUSO DE CONSTITUCIONALIDADE: PONDERAÇÕES À LUZ DA NOVA SISTEMÁTICA DE COISA JULGADA INTRODUZIDA PELO CÓDIGO DE PROCESSO CIVIL DE 2015}

DONIZETTI, Elpídio; CERQUEIRA, Marcelo Malheiros. Curso de Processo Coletivo: Contém Jurisprudência Temática e Índice Alfabético de Assuntos. São Paulo: Atlas, 2010.

FERNANDES, Bernardo Gonçalves. Curso de Direito Constitucional. 3.ed.rev.ampl.e atual. Rio de Janeiro: Lumen Juris, 2011.

GRINOVER, Ada Pellegrini. Relatório Geral - Civil Law: Os Processos Coletivos nos Países de Civil Law (Parte II: Novas Tendências em Matéria de Legitimação e Coisa Julgada nas Ações Coletivas). In: GRINOVER, Ada Pellegrini; WATANABE, Kazuo; MULLENIX, Linda. Os Processos Coletivos nos Países de Civil Law e Common Law: uma análise de direito comparado. 2.ed.rev.e atual. São Paulo: Editora Revista dos Tribunais, 2011.

GRINOVER, Ada Pellegrini. Coisa Julgada Erga Omnes, Secundum Eventum Litis e Secundum Probationem. In: GRINOVER, Ada Pellegrini; BENJAMIN, Antonio Herman; WAMBIER, Teresa Arruda Alvim; VIGORITI, Vincenzo [Orgs.]. Processo Coletivo: do Surgimento à Atualidade. São Paulo: Revista dos Tribunais, 2014a, pp.383-394.

GRINOVER, Ada Pellegrini. O Controle Difuso da Constitucionalidade e a Coisa Julgada Erga Omnes das Ações Coletivas. In: GRINOVER, Ada Pellegrini; BENJAMIN, Antonio Herman; WAMBIER, Teresa Arruda Alvim; VIGORITI, Vincenzo [Orgs.]. Processo Coletivo: do Surgimento à Atualidade. São Paulo: Revista dos Tribunais, 2014b, pp.487-492.

RODRIGUES, Roberto de Aragão Ribeiro. Notas sobre a Coisa Julgada nas Ações Coletivas. In: GRINOVER, Ada Pellegrini; BENJAMIN, Antonio Herman; WAMBIER, Teresa Arruda Alvim; VIGORITI, Vincenzo [Orgs.]. Processo Coletivo: do Surgimento à Atualidade. São Paulo: Revista dos Tribunais, 2014, pp.957-988.

THIBAU, Tereza Cristina Sorice Baracho. A legitimação ativa nas ações coletivas: um contributo para o estudo da substituição processual. Orientador: Aroldo Plínio Gonçalves. 2003. 295p. Tese (Doutorado em Direito). Faculdade de Direito da Universidade Federal de Minas Gerais, Belo Horizonte, 2003. 